\title{
Pengaruh Partisipasi Anggaran dan Kejelasan Tujuan Anggaran Terhadap Kinerja Aparat Pemerintah Daerah Kota Manado
}

\author{
Raykes H Tuerah \\ Jenny Morasa
}

\begin{abstract}
Enactment of Law No. 32 of 2004 on regional government and Law No. 33 On financial balance between central and regional governments, bringing fundamental changes in the relationship Governance Government Relations and Finance, as well as bringing significant changes in the management of the Regional Budget. Budget and Expenditure (Budget) approach is based on performance. Clarity describes the breadth budget budget stated clearly and in detail, and understood by the parties responsible for its achievement.

The purpose of this study was to determine the effect of budgetary goal characteristics include budgetary participation (X1) and clarity of purpose budget (X2), the performance of government officials (Y). While the object is examined in this study was 25 Unit (SKPD) in Manado City Government Environment.

The study population was a Regional Working Units government Manado samples in this study were taken by using purposive sampling method obtained a sample of 60 respondents in the study by using multiple regression analysis and tested first by using the classical assumption and test the validity and reliability of data tool SPSS version 14.0.

Characteristics of the test results budgetary purposes simultaneously have an influence on the performance of Manado city government. It is known to result Fhitung $=80.393$ and $F$ table $=2.37$ and sig. 0,000 count $<\alpha: 5 \%(0.05)$ so that Ha is accepted. As for the partial test ( $t$ test) budget participation, budget goal clarity, feedback, evaluation and budget difficulties budgetary purposes a significant effect on performance. From the calculation (PA) $t 2.697>2.000$ with significant ttable $0.009<\alpha: 5 \%(0.05)$ then $\mathrm{HO}$ is rejected and Ha accepted means calculation (KJA) t $2.541>2.000$ with significant ttable $0.014<\alpha: 5 \%$ ( 0.05) then $\mathrm{HO}$ is rejected means that Ha is accepted. Based on the survey results revealed that the factors characteristic of the budget goal Budget Participation and Budget Clarity of purpose affect the performance of Manado City Government Officials. And suggestions for government officials in this study should be further studied using objective characteristics of the budget in order to guide, reference or benchmark for every budget.
\end{abstract}

Keywords: Participation Budget, Budget Clarity, and Performance 


\section{PENDAHULUAN}

Pemahaman tentang anggaran menjadi modal bagi pimpinan dalam hal ini pejabat struktural yang menangani anggaran dan keuangan Pemerintah Daerah Kota Manado dalam menjalankan perencanaan dan pengendalian sehingga tujuan yang telah ditetapkan dapat dicapai secara optimal. Kinerja manajerial yang diperoleh dari upaya aparat merupakan salah satu faktor yang dapat digunakan untuk meningkatkan pengelolaan Pemerintah Daerah Kota Manado secara efektif. Michael dan Troy (2000) mengatakan bahwa kinerja manajerial adalah kinerja para individu anggota organisasi dalam kegiatan manajerial, antara lain perencanaan, investigasi, koordinasi, supervisi, pengaturan staf, negosiasi, dan representasi.Dalam Pedoman Penyusunan Pelaporan Akuntabilitas Kinerja Instansi Pemerintah yang dikeluarkan oleh Lembaga Administrasi Negara RI memberikan pengertian kinerja adalah gambaran mengenai tingkat pencapaian pelaksanaan suatu kegiatan/program/kebijaksanaan dalam mewujudkan sasaran, tujuan, misi, dan visi organisasi.

Penelitian ini akan mengkaji apakah Kinerja Aparat Pemerintah DaerahKota Manado berpengaruh terhadap beberapa karakteristik tujuan anggaran yang sudah disebutkan, dan dari keseluruhan latar belakang permasalahan yang telah diuraikan di depan, maka judul penelitian ini adalah "Pengaruh Partisipasi Anggaran dan Kejelasan Tujuan Anggaran Terhadap Kinerja Aparat Pemerintah Daerah Kota Manado”.

Rumusan masalah dari penelitian ini adalah "apakah partisipasi anggaran dan kejelasan tujuan anggaran berpengaruh terhadap kinerja Aparat Pemerintah Daerah ?"

Dengan hipotesis:

Ha1 : Partisipasi Anggaran berpengaruh terhadap kinerja aparat Pemerintah Daerah Kota Manado.

H01: Partisipasi Anggaran tidak berpengaruh terhadap kinerja aparat Pemerintah Daerah Kota Manado.

Ha2 : Kejelasan Tujuan Anggaran berpengaruh terhadap kinerja aparat Pemerintah Daerah Kota Manado.

H02: Kejelasn Tujuan Anggaran tidak berpengaruh terhadap kinerja aparat Pemerintah Daerah Kota Manado.

Sugiyono (2007 : 55) populasi adalah wilayah generalisasi yang terdiri atas; objek/subjek yang mempunyai kuantitas dan karakteristik tertentu yang diterapkan oleh peneliti untuk dipelajari dan kemudian ditarik kesimpulannya.populasi dari penelitian ini adalah seluruh aparat SKPD yang ada di Kota Manado. SKPD yang ada di Kota Manado berjumlah 130 terdiri dari 18 Dinas, 14 Badan dan lembaga teknis daerah, Sekertariat daerah dan sekertariat DPRD, 9 Kecamtan, dan 87 Kelurahan. Untuk kelurahan dengan jumlah 594 aparat tidak dijadikan populasi oleh karena masih merupakan SKPD dengan alokasi anggaran yang terbatas, sehingga populasi yang digunakan berjumlah 7.811 aparat yang ada di 43 SKPD.

Sugiyono (2007:56) sampel adalah sebagian dari jumlah dan karakteristik yang dimiliki oleh populasi tersebut.Bila populasi besar, dan peneliti tidak mungkin mempelajari semua yang ada pada populasi, maka peneliti dapat menggunakan sampel yang diambil dari populasi itu.

Mudrajad Kuncoro (2003) Sampel adalah suatu himpunan bagian dari populasi. Untuk pengambilan sampel dalam penelitian ini menggunakan metode purposive sampling yaitu pemilihan sekelompok subyek didasarkan atas ciri-ciri atau sifat-sifat tertentu yang dipandang mempunyai sangkut paut yang erat dengan ciri-ciri atau sifat-sifat populasi yang sudah diketahui sebelumnya.

Sampel terdiri atas sejumlah anggota yang dipilih dari populasi (Sekaran, 2006). Pemilihan sampel dalam penelitian ini didasarkan pada purposive sampling. Sampel dipilih berdasarkan kriteria tertentu sehingga dapat mendukung penelitian ini.Pengambilan sampel penelitian ini menggunakan carapurpsive sampling. Metode ini dipilih karena sampel akan diambil berdasarkan kriteria yang ditetapkan oleh peneliti, dimana kriteria pemilihan sampel adalah pejabat struktural dan staff di Satuan Kerja Perangkat Daerah Pemerintah Kota Manado yang memiliki peran dalam proses penyusunan anggaran (RKA-SKPD) dan memiliki masa kerja minimal satu tahun dalam periode penyusunan 
anggaran, adapun kriteria peneliti untuk penelitian ini adalah pejabat yang terlibat dalam penyusunan anggaran yaitu sekretaris, kepala bagian, kepala sub bagian dan staff. Berdasarkan kriteria tersebut di atas maka jumlah sampel penelitian sebanyak 78 orang dari populasi 25 SKPD Kota Manado (17 Dinas, 7 Badan dan 2 Bagian Adminitrasi).

Untuk mencapai tujuan penelitian seperti yang telah dikemukakan sebelumnya, maka digunakan metode analisa regresi linear berganda. Menurut Agus Irianto (2004:101), analisis regresi linear berganda digunakan oleh peneliti bila peneliti bermaksud meramalkan bagaimana keadaan (naik turunnya) variabel dependen bila dua atau lebih variabel independen sebagai faktor prediktor dimanipulasi (dinaik turunkan nilainya) dengan menggunakan formula.

Untuk menyelesaikan analisis data ini secara keseluruhan, peneliti akan menggunakan bantuan teknologi komputer. Aplikasi statistik yang akan digunakan dalam penelitian ini adalah Software SPSS (Statistics Package for the Social Sciences) Program Version 18.0 for Windows dimana telah ditetapkan tingkat keyakinan sebesar 95\% dan tingkat signifikan sebesar 5\%. Semua hasil output data yang dihasilkan kemudian diinterpretasikan satu per satu termasuk didalamnya menentukan koefisien korelasi (R) dan koefisien determinasi $\left(\mathrm{R}^{2}\right)$.

Secara keseluruhan, analisis data ini menggunakan bantuan komputer dengan software program SPSS for windows tanpa menggunakan perhitungan manual. Sebelum melakukan analisis data, penulis terlebih dahulu melakukan pengujian kualitas data yang diperoleh. Uji kualitas data dilakukan untuk meyakinkan kualitas data yang akan diolah yang terdiri dari pengujian validitas dan reliabilitas.

Berbeda dengan alat analisis lainnya, regresi linear ganda memerlukan uji persyaratan yang ketat. Uji persyaratan pada regresi linear ganda biasa disebut dengan istilah uji asumsi klasik. Dalam melakukan pengujian hipotesis dengan menggunakan statistik parametrik, khususnya dalam penggunaan statistik regresi linear ganda diperlukan persyaratan yang harus dipenuhi. Persyaratan awal, untuk menggunakan regresi sebagai salah satu alat analisis yaitu variabel penelitian harus diukur paling rendah dalam bentuk skala interval (Gunawan, 2005). Apabila variable-variabel penelitian tersebut diukur dalam bentuk skala interval, maka telah memenuhi salah satu persyaratan awal untuk menggunakan statistik parametrik. Tentu saja timbul pertanyaan, mengapa data harus minimal berskala interval. Hal ini dapat dijelaskan, bahwa dalam statistik parametrik penghitungan-penghitungan yang dilakukan tidak hanya sekedar menghitung berapa besarnya frekuensi, seringnya sesuatu terjadi dan yang sejenisnya, akan tetapi lebih dari itu, yaitu dilakukan juga penjumlahan, pengurangan, perkalian, dan pembagian. Data yang dapat dijumlahkan, dikurangkan, dikalikan dan juga dibagi hanyalah data yang minimal berskala interval. Data yang berskala ordinal bahkan berskala nominal tidak dapat dijumlahkan, dikurangkan, dikalikan dan juga dibagi.Hal inilah yang menyebabkan mengapa statistik parametrik memerlukan data minimal berskala interval atau yang lebih tinggi lagi, yaitu data yang berskala rasio.

Selain data harus berskala interval, beberapa persyaratan berikutnya yang juga harus dipenuhi antara lain berupa persyaratan untuk analisis regresi linear ganda, antara lain terdiri dari (a) normalitas (b) tidak terjadi adanya heteroskedastisitas (c) tidak terdapat saling hubungan antara variabel bebas satu dengan variabel bebas lainnya (uji multikolinearitas) dan (d) tidak terdapat autokorelasi antar data pengamatan. Oleh karena itu, sebelum melakukan uji hipotesis terlebih dahulu dilakukan uji persyaratan untuk menggunakan regresi linear ganda (Gunawan, 2005). Menurut Gunawan (2005), beberapa hal yang mendasari tentang perlunya melakukan uji asumsi klasik atau uji persayaratan tersebut yaitu agar besaran atau koefisien statistik yang diperoleh benar-benar merupakan penduga parameter yang memang dapat dipertanggungjawabkan atau akurat.

Selanjutnya untuk menguji hipotesis yang diajukan, maka digunakan statistik uji F dan uji t. Uji $\mathrm{F}$ adalah untuk menguji pengaruh variabel bebas secara simultan atau bersama-sama.

Dengan kriteria pengujian, jika $F_{\text {hitung }}>F_{\text {tabel }}$ maka $\mathrm{H}_{0}$ ditolak berarti Ha diterima atau dengan menggunakan kriteria lain yaitu apabila signifikan $<0,05$ maka $\mathrm{H}_{0}$ ditolak, Ha diterima dan apabila 
signifikan $>0,05$ maka $\mathrm{H}_{0}$ diterima, Ha ditolak. Uji t adalah untuk menguji pengaruh variabel bebas secara parsial atau sendiri-sendiri.

Dengan kriteria pengujian, jika $t_{\text {hitung }}>t_{\text {tabel }}$ maka $\mathrm{H}_{0}$ ditolak berarti Ha diterima atau dengan menggunakan kriteria lain yaitu apabila signifikan $<0,05$ maka $\mathrm{H}_{0}$ ditolak, Ha diterima dan apabila signifikan $>0,05$ maka $\mathrm{H}_{0}$ diterima, Ha ditolak.

\section{LANDASAN TEORI}

\subsection{Partisipasi Anggaran}

Partisipasi penyusunan anggaran merupakan pendekatan yang secara umum dapat meningkatkan kinerja yang pada akhirnya dapat meningkatkan efektivitas organisasi.menyatakan bahwa partisipasi sebagai alat untuk mencapai tujuan, partisipasi juga sebagai alat untuk mengintegrasikan kebutuhan individu dan organisasi. Sehingga partisipasi dapat diartikan sebagai berbagi pengaruh, pendelegasian prosedur-prosedur, keterlibatan dalam pengambilan keputusan dan suatu pemberdayaan. Partisipasi yang baik membawa beberapa keuntungan sebagai berikut: (1) member pengaruh yang sehat terhadap adanya inisiatif, moralisme dan antusiasme, (2) memberikan suatu hasil yang lebih baik dari sebuah rencana karena adanya kombinasi pengetahuan dari beberapa individu, (3) dapat meningkatkan kerjasama antar departemen, dan (4) para karyawan dapat lebih menyadari situasi di masa yang akan datang yang berkaitan dengan sasaran dan pertimbangan lain Irvine (1978) dalam Nor (2007). Partisipasi penyusunan anggaran yang begitu luas menunujukkan betapa luasnya partisipasi bagi aparat pemerintah untuk memahami anggaran yang diusulkan oleh unit kerjanya sehingga berpengaruh terhadap tujuan pusat pertanggunjawaban anggaran mereka.

Partisipasi anggaran yaitu tingkat pengaruh dan keterlibatan yang dirasakan oleh individu dalam proses perencanaan anggaran (Bastian, 2006). Partisipasi anggaran tersebut menunjukkan pada luasnya partisipasi aparat pemerintah daerah dan merupakan semua penerimaan daerah yang berasal dari sumber ekonomi daerah yang dipungut berdasarkan Peraturan Daerah sesuai dengan peraturan perundang-undangan yang berlaku.

\subsection{Kejelasan Tujuan Anggaran}

Anggaran Pendapatan dan Belanja Daerah sebagai rencana kerja pementah daerah merupakan desain teknis pelaksanaan strategi untuk mencapai tujuan daerah. Jika kualitas anggaran pemerintah daerah rendah, maka kualitas fungsi-fungsi pemerintah cenderung lemah anggaran daerah seharusnya tidak hanya berisi mengenai informasi pendapatan dan penggunaan dana belanja, tetapi harus menyajikan informasi kondisi kinerja yang ingin dicapai. Anggaran Pemerintah Daerah harus menjadi tolak ukur pencapaian kinerja yang diharapkan, sehingga perencanaan anggaran pemerintah daerah harus bisa menggambarkan sasaran kinerja secara jelas

Kejelasan tujuan anggaran menunjukkan luasnya tujuan anggaran yang dinyatakan secara spesifik dan jelas, dan dimengerti oleh siapa saja yang bertanggung jawab.Manajer memberi reaksi positif dan secara relatif sangat kuat untuk meningkatkan kejelasan tujuan anggaran. Manajemen tingkat atas dapat meningkatkan kepuasan kerja, menurunkan ketegangan kerja, dan memperbaiki anggaran yang dihubungkan dengan sikap, kinerja anggaran, dan efisiensi biaya manajer tingkat bawah secara signifikan meningkatkan kejelasan dan ketegasan tujuan anggaran mereka

\section{GAMBARAN UMUM OBJEK PENELITIAN}

Objek penelitian dalam hal ini adalah pejabat struktural SKPD (SatuanKerja Perangkat Daerah) Pemerintah Kota Manado yang terlibat dalamproses penyusunan anggaran. Jumlah SKPD di Kota Manado sebanyak 130 SKPD yang terdiri dari 18 dinas, 14 lembaga teknis (badan, kantor, inspektorat) 3 sekretariat ( 9 bagian) secretariat DPRD, 9 kecamatan, 87 kelurahan dan 2 perusahaan daerah pasar dan air minum. Sampel penelitian ini dipilih dengan metode purposive sampling dengan kriteria pejabat struktural SKPD Pemerintah Kota Manado yang terlibat dalam proses penyusunan anggaran (RKASKPD). Kuesioner dibagikan kepada 25 SKPD (17 dinas, 7 badan dan 2 bagian Administrasi 
Umum) Pemerintah Kota Manado dengan jumlah 78 kusioner, namun ada SKPD yang menolak dan tidak merespon untuk mengisi kuesioner denganalasan kesibukan SKPD tersebut. SKPD yang bersedia mengisi kuesioner sebanyak 22 SKPD (60 orang). Kuesioner dibagikan kepada pejabat structural yaitu sekertaris, kepala bagian, kepala sub bagian dan staff dari masing-masing SKPD yang terlibat dalam proses penyusunan RKA-SKPD.

\section{HASIL PENELITIAN}

Dari hasil perhitungan pengujian statistik deskriptif yang dilakukan pada Tabel 4.3 dapat diartikan sebagai berikut.

1. Rata-rata partisipsi anggaran (dengan jumlah data 60) adalah sebesar 20.1167dengan standar deviasi 3.49863 dengan range 14.00

2. Rata-rata partisipsi anggaran (dengan jumlah data 60) adalah sebesar 20.500 dengan standar deviasi 3.49863 dengan range 13.00

3. Rata-rata kinerja (dengan jumlah data 60) adalah sebesar20.7833dengan standar deviasi 3.66889 dengan range 15.00

\section{Uji Validitas dan Reliabilitas}

\section{Uji Validitas}

Pengujian validitas dengan menggunakan software statistic, nilai validitas dilihat dari kolom Corrected Item Total Correltion. Jika angka korelasi yang diperoleh lebih besar dari pada angka kritik ( $\mathrm{r}$ hitung $>\mathrm{r}$ tabel) maka instrument dapat dikatakan valid. Sampel sebanyak 60 responden dan $\mathrm{r}$ tabel adalah 0,254 sebagaimana dapat dilahat pada tabel dibawah ini

\begin{tabular}{|l|c|c|c|}
\hline & & & \\
& r hitung & r tabel & Keteranagan \\
\hline Partisipasi anggaran & .913 & .254 & Valid \\
Kejelasan tujuan anggaran & .913 & .254 & Valid \\
Kinerja & .859 & .254 & Valid \\
\hline
\end{tabular}

\section{Uji Reliabilitas}

Uji reliabilitas menunjukkan Cronbach's Alpha lebih besar dari 0.6 maka dapat dinyatakan instrument maka dapat dinyatakan instrument tersebut reliable.Uji reliabilitas dilakukan untuk menunjukkan sejauh mana suatu alat pengukur dapat dipercaya. Koefisien Cronbach's Alpha> 0,6, hal ini menunjukkan bahwa data penelitian dinyatakan reliable.

\begin{tabular}{|l|c|c|c|}
\hline \multicolumn{1}{|c|}{ Variable } & $\begin{array}{c}\text { Cronbach's } \\
\text { Alpha }\end{array}$ & $\begin{array}{c}\text { Batas } \\
\text { Reliabilitas }\end{array}$ & Keterangan \\
\hline Partisipasi anggaran & .909 & $\mathbf{0 , 6}$ & Reliabel \\
Kejelasan Anggaran & .914 & $\mathbf{0 , 6}$ & Reliabel \\
Kinerja Aparat & .954 & $\mathbf{0 , 6}$ & Reliabel \\
\hline
\end{tabular}




\section{Pengujian Asumsi Klasik}

1. Uji Normalitas

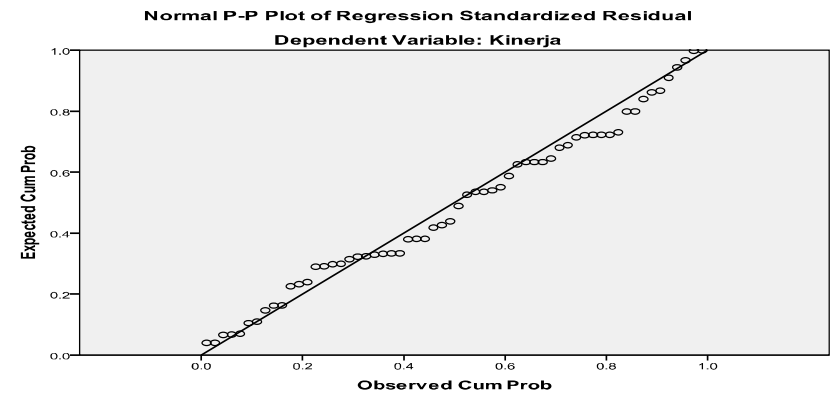

Dari Gambar dapat dilihat bahwa data menyebar disekitar garis diagonal dan mengikuti arah garis diagonal, maka dapat dikatakan bahwa model regresi layak dipakai untuk memprediksikan kinerja aparat berdasarkan variable independennya yaitu karakteristik tujuan anggaran

\section{Uji Asumsi Klasik Heteroskedastisitas}

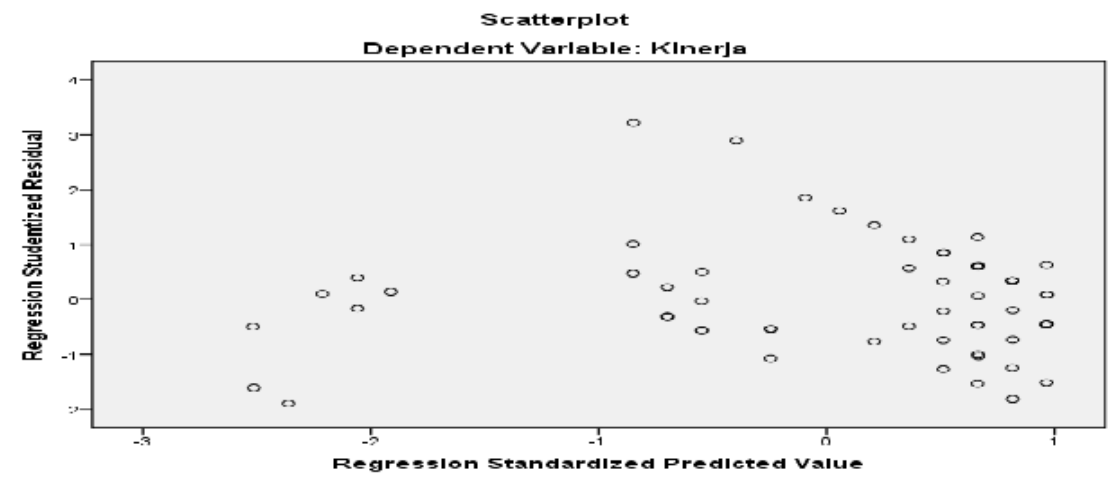

Dari Gambar 4.2. Nampak bahwa diagram pencar residual tidak membentuk suatu pola tertentu atau posisinya dalam keadaan menyebar serta tersebar baik di atas maupun di bawah angka 0 pada sumbu Y. Kesimpulannya, model regresi terbebas dari kasus heteroskedastisitas dan memenuhi persyaratan asumsi klasik tentang heteroskedastisitas sehingga model regresi layak dipakai untuk memprediksi kinerja aparat pemerintah berdasarkan variable independennya.

3. Uji Asumsi Klasik Multikolinearitas

\begin{tabular}{|cc|r|c|}
\hline \multirow{2}{*}{ Model } & \multicolumn{2}{|c|}{$\begin{array}{c}\text { Collinearity } \\
\text { Statistics }\end{array}$} \\
\cline { 3 - 4 } & & Tolerance & \multicolumn{1}{c|}{ VIF } \\
\hline 1 & P.angg & .163 & 6.120 \\
& K.angg & .163 & 6.120 \\
\hline
\end{tabular}

a. Dependent Variable: Kinerja

Dari Tabel 4.7 nilai VIF menunjukkan angka sebesar 6,$120 ; 6.120$ yang menyatakan bahwa nilai VIF untuk variabel $\mathrm{X}$ secara keseluruhan $<10$ maka dapat disimpulkan bahwa tidak terjadi multikolinearitas dalam model regresi.

\section{Uji Asumsi Klasik Autokorelasi}

\begin{tabular}{|r|r|}
\hline $\begin{array}{c}\text { Std. Error of } \\
\text { the Estimate }\end{array}$ & $\begin{array}{c}\text { Durbin- } \\
\text { Watson }\end{array}$ \\
\hline 1.909461 & 1.737 \\
\hline
\end{tabular}


Dari Tabel 4.8 dapat dilihat bahwa nilai Durbin Watson $(D W)$ sebesar $\mathbf{1 , 7 3 7}$ atau menunjukkan bahwa nilai $1,65<\mathrm{DW}<2,35$ maka dapat disimpulkan bahwa tidak terjadi autokorelasi dalam model regresi.

\section{Koefisien Korelasi dan Determinasi}

\section{Koefisien Korelasi (R)}

Analisis ini digunakan untuk mengukur tingkat hubungan antara variabel bebas $(\mathrm{X})$ terhadap variabel terikat (Y). Dalam hal ini mengukur kuat atau lemahnya hubungan antara karakteristik tujuan anggaran (X) dengan kinerja aparat Pemerintah (Y).

Tabel 4.9

\begin{tabular}{|c|c|r|r|}
\hline $\begin{array}{c}\text { Mode } \\
1\end{array}$ & \multicolumn{1}{c|}{ R } & R Square & $\begin{array}{r}\text { Adjusted } \\
\text { R Square }\end{array}$ \\
\hline 1 & $.859(\mathrm{a})$ & .738 & .729 \\
\hline
\end{tabular}

Dari Tabel 4.9 dapat dilihat bahwa koefisien korelasi linear yang diperoleh adalah sebesar 0,859. Angka ini menunjukkan bahwa hubungan antara variabel bebas (X) dengan variabel terikat $(\mathrm{Y})$ sangat kuat karena hampir mendekati angka satu (1), serta angka korelasi yang dihasilkan menunjukkan angka positif $(+)$ yang berarti bahwa hubungan kedua variabel searah.

\section{Koefisien Determinasi $\left(\mathbf{R}^{2}\right)$}

Koefisien determinasi diperlukan untuk mengukur seberapa besar pengaruh karakteristik tujuan anggaran yang meliputi partisipasi anggaran dan kejelasan tujuan anggaran terhadap kinerja aparat Pemerintah (Y). Berdasarkan hasil perhitungan dengan menggunakan bantuan program SPSS Version 14.0 seperti yang nampak pada Tabel, maka dapat diketahui nilai AdjustedR square yang diperoleh adalah sebesar 0,729 atau 72,9\%. Adapun nilai ini memberikan arti bahwa kinerja aparat Pemerintah Daerah Kota Manado dipengaruhi oleh faktor karakteristik tujuan anggaran yang meliputi partisipasi anggaran dan kejelasan tujuan anggaran sebesar $72.9 \%$, sedangkan sisanya sebesar $27,1 \%$ dijelaskan faktor-faktor atau variabel lain yang tidak diteliti dalam penelitian ini.

\section{Analisis Regresi Berganda}

\begin{tabular}{|c|c|c|c|c|c|c|}
\hline \multirow{2}{*}{\multicolumn{2}{|c|}{ Model }} & \multicolumn{2}{|c|}{$\begin{array}{c}\text { Unstandardized } \\
\text { Coefficients }\end{array}$} & \multirow{2}{*}{$\begin{array}{c}\text { Standardized } \\
\text { Coefficients }\end{array}$} & \multirow[b]{2}{*}{$\mathrm{t}$} & \multirow[b]{2}{*}{ Sig. } \\
\hline & & $\mathrm{B}$ & Std. Error & & & \\
\hline & (Constant) & 1.401 & 1.585 & & .884 & .381 \\
\hline & P.angg & .474 & .176 & .452 & 2.697 & .009 \\
\hline & K.angg & .480 & .189 & .426 & 2.541 & .014 \\
\hline
\end{tabular}

a. Dependent Variable: Kinerja

Dari Tabel 4.10 dapat diketahui bahwa model regresi yang diperoleh adalah :

$$
\begin{gathered}
Y=\alpha+\beta_{1} X_{1}+\beta 1 X_{2}+e \\
Y=1.401+0,474 X+0.480
\end{gathered}
$$

Hasil konstanta a sebesar 1.401 memberikan pengertian bahwa jika keseluruhan karakteristik tujuan anggaran yang meliputi partisipasi anggaran, kejelasan tujuan anggaran, umpan balik anggaran, evaluasi anggaran, dan kesulitan tujuan anggaran konstan atau sama dengan nol (0), maka besarnya kinerja aparat Pemerintah Kota Manado sebesar 1,401 satuan.

Selanjutnya nilai $b_{1}$ yang merupakan koefisien regresi dari variabel $X_{1}$ (partisipasi anggaran) sebesar 0,474 mempunyai arti bahwa semakin banyaknya pengambilan partisipasi anggaran dalam suatu penyusunan atau penetapan rencana anggaran dalam setiap SKPD, maka kinerja aparat Pemerintah Daerah Kota Manado akan mengalami peningkatan sebesar 0,474 satuan dengan asumsi variabel lainnya tetap atau konstan. 
Nilai $b_{2}$ yang merupakan koefisien regresi dari variabel $\mathrm{X}_{2}$ (kejelasan tujuan anggaran) sebesar 0,480 mempunyai arti bahwa semakin jelasnya tujuan anggaran yang dibuat oleh setiap SKPD, maka akan membuat kinerja aparat Pemerintah Daerah Kota Manado menjadi meningkat sebesar 0,480 satuan dengan asumsi variabel lainnya tetap atau konstan.

\section{Hasil Pengujian}

1. Uji

\begin{tabular}{|c|c|c|c|c|c|c|}
\hline \multicolumn{7}{|c|}{ ANOVA $^{b}$} \\
\hline & & $\begin{array}{c}\text { Sum of } \\
\text { Squares }\end{array}$ & Df & $\begin{array}{l}\text { Mean } \\
\text { Square }\end{array}$ & $\mathrm{F}$ & Sig. \\
\hline \multirow[t]{3}{*}{1} & Regression & 586.327 & 2 & \multirow{3}{*}{$\begin{array}{r}293.163 \\
3.647\end{array}$} & \multirow[t]{3}{*}{80.393} & \multirow[t]{3}{*}{$.000^{\circ}$} \\
\hline & Residual & 207.857 & 57 & & & \\
\hline & Total & 794.183 & 59 & & & \\
\hline
\end{tabular}

a. Predictors: (Constant), K.angg, P.angg

b. Dependent Variable: Kinerja

\section{Sumber : Output Pengolahan Data SPSS, 2012}

Dari Tabel 4.11 dapat diketahui hasil $F_{\text {hitung }}=80,393$ dan $F_{\text {tabel }}=2,37$. Jadi nampak bahwa $\mathrm{F}_{\text {hitung }}>\mathrm{F}_{\text {tabel }}$ maka $\mathrm{H}_{0}$ ditolak berarti $\mathrm{Ha}$ diterima. Atau dapat juga dilihat bahwa signifikan $\mathrm{F}_{\alpha 0,05}$ sebesar 0,000 ini menunjukkan bahwa $\mathrm{H}_{0}$ ditolak dan Ha diterima.

Dengan demikian hasil uji $\mathrm{F}$ menyatakan bahwa $\mathrm{H}_{0}$ ditolak berarti Ha diterima, artinya secara keseluruhan faktor-faktor karakteristik tujuan anggaran yang meliputi partisipasi anggaran dan kejelasan tujuan anggaran berpengaruh secara signifikan terhadap kinerja aparat Pemerintah Daerah Kota Manado.

Uji t

Dari Tabel 4.10 dapat diketahui hasil $t_{\text {hitung }}$ untuk variabel X1(partisipasi anggaran) $=2.697$ dan $t_{\text {tabel }}=2,000$. Karena $t_{\text {hitung }}>t_{\text {tabel }}$ maka $\mathrm{H}_{0}$ ditolak berarti Ha diterima. Atau dapat juga dilihat signifikan

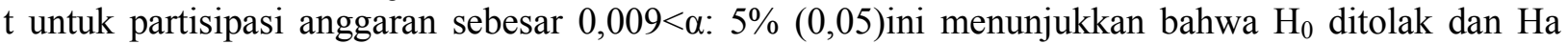
diterima. Artinya faktor partisipasi anggaran berpengaruh secara signifikan terhadap kinerja aparat Pemerintah Daerah Kota Manado.

Selanjutnya hasil $t_{\text {hitung }}$ untuk variabel $X_{2}$ (kejelasan tujuan anggaran $)=2,541$ dan $t_{\text {tabel }}=2,000$. Karena $t_{\text {hitung }}>t_{\text {tabel }}$ maka $\mathrm{H}_{0}$ ditolak berarti Ha diterima. Atau dapat juga dilihat signifikan $t$ untuk kejelasan tujuan anggaran sebesar $0,014<\alpha$ : 5\% $(0,05)$ ini menunjukkan bahwa $\mathrm{H}_{0}$ ditolak dan $\mathrm{Ha}$ diterima. Artinya faktor kejelasan tujuan anggaran berpengaruh secara signifikan terhadap kinerja aparat Pemerintah Daerah Kota Manado.

\section{Evaluasi Data}

Penelitian atas pengaruh partisipasi anggaran terhadap kinerja kinerja aparat pemerintah kota Manado menggunakan data kualitatif yang dikuantitatifkan dengan menggunakan skala likert dan bersumber dari data primer. Pengumpulan data ini dilakukan dengan mengedarkan kuisioner oleh peneliti kepada responden yang ada di kantor pemerintah kota Manado. Kuisioner yang diedarkan mulai awal bulanNovember 2011 dan dikumpulkan pada pertengahan Januari 2012.

Sebelum kuisioner diedarkan telah dilakukan uji kualitas data dengan menggunakan uji validitas dan reliabilitas. Hasil uji validitas melaui Software SPSS Version 18.0 menunjukan nilai tertinggi data yang terdapat pada kuisioner untuk variable partisipasi anggaran (X1) 0,913, kejelasan tujuan anggaran (X2) 0.913 dan kinerja (Y) adalah 0.859 . Hal ini dapat dikatakan seluruh data yang terdapat pada variable bebas dan terikat adalah valid karena nilai Pearson Correlation lebih besar dari 0,254. Hasil uji reliabilitas melalui metode Cronbach Alpha dalam Software SPSS Version 18.0 menunjukan nilai data yang terdapat pada kuisioner untuk variable partisipasi anggaran (X1) 0,909, kejelasan tujuan anggaran (X2) 0.914 dan kinerja (Y) 0,954. Nilai tersebut berada pada kelompok Alpha 0,60 s.d 0,80 dengan kategori reliabel. Hal ini dapat 
dikatakan seluruh data yang terdapat pada variable bebas dan terikat adalah reliabel karena nilai Pearson Correlation lebih besar dari 0,60.

Sehubungan dengan penggunaan metode analisis regresi sederhana, maka dilakukan pengujian asumsi klasik melalui uji normalitas,uji heteroskedastisitas, uji multikolinearitas, danuji autokorelasi.Dari hasil uji normalitas Dari Gambar 4.1 dapat dilihat bahwa data menyebar disekitar garis diagonal dan mengikuti arah garis diagonal, maka dapat dikatakan bahwa model regresi layak dipakai untuk memprediksikan kinerja aparat berdasarkan variable independennya yaitu karakteristik tujuan anggaran. Pada uji heteroskedastisitas. Dari Gambar 4.2. Nampak bahwa diagram pencar residual tidak membentuk suatu pola tertentu atau posisinya dalam keadaan menyebar serta tersebar baik di atas maupun di bawah angka 0 pada sumbu Y. Kesimpulannya, model regresi terbebas dari kasus heteroskedastisitas dan memenuhi persyaratan asumsi klasik tentang heteroskedastisitas sehingga model regresi layak dipakai untuk memprediksi kinerja aparat pemerintah berdasarkan variable independennya. Hasil uji multikolinearitas Dari Tabel 4.7 nilai VIF menunjukkan angka (X1) sebesar 6.120 dan (X2) sebesar 6,120 yang menyatakan bahwa nilai VIF untuk variabel X secara keseluruhan $<10$ maka dapat disimpulkan bahwa tidak terjadi multikolinearitas dalam model regresi. Untuk uji autokorelasi Dari Tabel 5.10 dapat dilihat bahwa nilai Durbin Watson $(D W)$ sebesar 1,737 atau menunjukkan bahwa nilai 1,65 $<\mathrm{DW}<2,35$ maka dapat disimpulkan bahwa tidak terjadi autokorelasi dalam model regresi.

Dari hasil pengujian koefisien dapat dilihat pada Tabel 4.9 bahwa koefisien korelasi linear yang diperoleh adalah sebesar 0,859. Angka ini menunjukkan bahwa hubungan antara variabel bebas (X) dengan variabel terikat (Y) sangat kuat karena hampir mendekati angka satu (1), serta angka korelasi yang dihasilkan menunjukkan angka positif $(+)$ yang berarti bahwa hubungan kedua variabel searah dan Koefisien determinasi diperlukan untuk mengukur seberapa besar pengaruh karakteristik tujuan anggaran yang meliputi partisipasi anggaran, kejelasan tujuan anggaran, umpan balik anggaran, evaluasi anggaran, dan kesulitan tujuan anggaran terhadap kinerja aparat Pemerintah (Y). Berdasarkan hasil perhitungan dengan menggunakan bantuan program SPSS Version 14.0 seperti yang nampak pada Tabel, maka dapat diketahui nilai Adjusted $R$ square yang diperoleh adalah sebesar 0,729 atau $72,9 \%$. Adapun nilai ini memberikan arti bahwa kinerja aparat Pemerintah Daerah Kota Manado dipengaruhi oleh faktor karakteristik tujuan anggaran yang meliputi partisipasi anggaran dan kejelasan tujuan anggaran sebesar $72,9 \%$, sedangkan sisanya sebesar $27,1 \%$ dijelaskan faktor-faktor atau variabel lain yang tidak diteliti dalam penelitian ini.

Adapun nilai $b_{1}$ yang merupakan koefisien regresi dari variabel $\mathrm{X}_{1}$ (partisipasi anggaran) sebesar 0,474 mempunyai arti bahwa semakin banyaknya pengambilan partisipasi anggaran dalam suatu penyusunan atau penetapan rencana anggaran dalam setiap SKPD, maka kinerja aparat Pemerintah Daerah Kota Manado akan mengalami peningkatan sebesar 0,474 satuan dengan asumsi variabel lainnya tetap atau konstan. Hasil ini didukung dengan pengujian hipotesis $t$ yang menunjukkan hasil $t_{\text {hitung }}$ untuk variabel $\mathrm{X} 1$ (partisipasi anggaran) $=2.697$ dan $t_{\text {tabel }}=2,000$. Karena $t_{\text {hitung }}>t_{\text {tabel }}$ maka $\mathrm{H}_{0}$ ditolak berarti Ha diterima. Atau dapat juga dilihat signifikan $t$ untuk partisipasi anggaran sebesar 0,009 < : 5\% (0,05)ini menunjukkan bahwa $\mathrm{H}_{0}$ ditolak dan Ha diterima. Artinya faktor partisipasi anggaran berpengaruh secara signifikan terhadap kinerja aparat Pemerintah Daerah Kota Manado.

Hasil temuan pertama dalam penelitian ini menunjukkan bahwa terdapat pengaruh yang positif dan signifikan variabel partisipasi anggaran terhadap variabel kinerja aparat pemerintah daerah kota Manado, ini berarti bahwa peningkatan atas partisipasi aparat Pemda dalam pembuatan tujuan anggaran akan meningkat kinerja aparat Pemda,sebaliknya jika partisipasi aparat Pemda dalam pembuatan tujuan anggaran turun maka kinerja aparat Pemda juga akan turun. Oleh karena itu hipotesis Ha dalam penelitian ini diterima.Argyris (1952) dan dikembangan oleh Nor (2007) yang telah menemukan partisipasi dari bawahan memegang peran sentral dalam pencapaian tujuan. Dengan adanya keterlibatan manajer atau kepala unit organisasi dalam proses penganggaran, akan memberikan 
implikasi terhadap kejelasan tugas dan target yangdicapai, sehingga membantu manajer mencapai tujuan organisasi sebagaimana dalam perencanaan anggaran.

Hasil ini juga semakin memperkuat penelitian Munawar (2006), yang menemukan bahwa partisipasi anggaran berpengaruh terhadap kinerja aparat pemerintah daerah Kab.Kupang. Hal ini menunjukkan bahwa anggaran yang dibuat oleh aparat pemerintah daerah adalah spesifik dan jelas, sehingga meningkatkan kinerja aparat pemerintah daerah. Begitu juga penelitian Sartdijo (2007), Frisilia Harfiz (2007) dan Istiyani (2009) yang menemukan dalam penelitiannya partisipasi anggaran berpangaruh terhadap kinerja aparat pemerintah.

Selanjutnya Nilai $b_{2}$ yang merupakan koefisien regresi dari variabel $\mathrm{X}_{2}$ (kejelasan tujuan anggaran) sebesar 0,480 mempunyai arti bahwa semakin jelasnya tujuan anggaran yang dibuat oleh setiap SKPD, maka akan membuat kinerja aparat Pemerintah Daerah Kota Manado menjadi meningkat sebesar 0,480 satuan dengan asumsi variabel lainnya tetap atau konstan. Selanjutnya hasil $t_{\text {hitung }}$ untuk variabel $\mathrm{X}_{2}$ (kejelasan tujuan anggaran) $=2,541$ dan $\mathrm{t}_{\text {tabel }}=2,000$. Karena $\mathrm{t}_{\text {hitung }}>\mathrm{t}_{\text {tabel }}$ maka $\mathrm{H}_{0}$ ditolak berarti Ha diterima. Atau dapat juga dilihat signifikan t untuk kejelasan tujuan anggaran sebesar $0,014<\alpha$ : 5\% $(0,05)$ ini menunjukkan bahwa $\mathrm{H}_{0}$ ditolak dan Ha diterima. Artinya faktor kejelasan tujuan anggaran berpengaruh secara signifikan terhadap kinerja aparat Pemerintah Daerah Kota Manado.

Hasil temuan kedua dalam penelitian ini menunjukkan bahwa terdapat pengaruh yang positif dan signifikan variabel kejelasan tujuan anggaran terhadap variabel kinerja aparat Pemda, ini berarti bahwa semakin jelas kejelasan tujuan anggaran dalam penyusunan anggaran makan semakin tinggi kinerja aparat pemda dalam melaksanakan tugas dan tanggung jawabnya, sebaliknya jika tujuan anggaran kurang jelas maka kinerja aparat Pemda juga akan turun. Oleh karena itu hipotesis Ha dalam penelitian ini diterima.Bastian (2006) yang menyimpulkan bahwa salah satu kunci kinerja yang efektif adalah kejelasan tujuan penganggaran memegang peran sentral dalam pencapaian tujuan. Dengan tujuan yang jelas dalam proses penganggaran, akan memberikan implikasi terhadap kejelasan tugas dan target yang dicapai, sehingga membantu manajer mencapai tujuan organisasi sebagaimana dalam perencanan anggaran.

Hasil ini juga didukung oleh penelitian Istiyani (2009) studi kasus Pemerindah Daerah Kabupaten Temanggung menemukan kejelasan tujuan anggaran berpengaruh terhadap kinerja Pemerintah Temanggung. Hasil ini juga sejalan dengan hasil penelitian Mochamad Solicin (2009) yang meneliti pengaruh karakteristik tujuan anggaran terhadap kinerja dengan subjek penelitian Aparat Pemerintah Kota Yogyakarta menemukan bahwa kejelasan tujuan anggaran memiliki pengaruh kuat terhadap kinerja penganggaran, berbeda dengan penemuan Agus Setiawan (2010) yang menemukan bahwa kejelasan tujuan anggaran tidak berpengaruh terhadap kinerja aparat Pemerinah Daerah Sukoharjo.

Peneliti menyimpulkan bahwa penetapan tujuan spesifik akan lebih produktif daripada tidak menetapkan tujuan spesifik. Hal ini akan mendorong karyawan untuk melakukan yang terbaik bagi pencapaian tujuan yang dikehendaki dan menemukan bahwa kejelasan tujuan berhubungan dengan kinerja.

\section{KESIMPULAN DAN SARAN}

Pada penelitian ini penulis bertujuan apakah variable karakteristik tujuan anggaran antara lain partisipasi anggaran dan kejelasan tujuan anggaran berpengaruh terhadap kinerja aparat Pemerintah Kota Manado.

Dari hasil pengujian dan analisis statistik dalam penelitian ini, dapat diambil kesimpulan antara lain sebagai berikut:

1. Dari hasil pengujian bersama-sama simultan atau uji $\mathrm{F}$ karakteristik tujuan anggaran secara simultan berpengaruh signifikan terhadap kinerja aparat Pemerintah Kota Manado. Pengaruh 
ini di tinjau dari koefisien determinasi dimana angka yang di peroleh $80.3 \%$ Sedangkan sisanya disebabkan oleh faktor-faktor lain atau variable-variable lain yang tidak diteliti.

2. Hasil pengujian uji parsial atau uji t partisipasi anggaran bepengaruh signifikan terhadap kinerja aparat pemerintahan. Partisipasi adalah tahap partisipasi pengurus dalam menyusun anggaran pengaruh partisipasi anggaran tersebut terhadap pusat pertanggungjawaban. mendefenisikan bahwa anggaran adalah suatu proses partisipasi individu akan dinilai dan mungkin diberi penghargaan atas prestasi mereka pada tujuan yang dianggarkan, dan mereka terlibat dalam proses tersebut dan mempunyai pengaruh pada penentuan tujuan tersebut. Dengan banyaknya partisipasi individu anggaran maka kinerja yang dihasilkan akan lebih mudah tecapai.

3. Hasil pengujian uji parsial atau uji t kejelasan anggran anggaran bepengaruh signifikan terhadap kinerja aparat pemerintahan. Kejelasan tujuan anggaran menunjukkan sejauhmana tujuan anggaran program dan kegiatan SKPD dinyatakan secara spesifik, jelas dan dimengerti oleh siapa saja yang bertanggung jawab terhadap anggaran dan juga merupakan perbandingan antara efisiensi rencana dan efisiensi aktual yang masing-masing dihasilkan dari perbandingan output dan input suatu kegiatan. Oleh sabab itu semakin jelasnya sasaran anggaran terhadap kinerja maka penetapan tujuan spesifik akan lebih produktif dari pada tidak menetapkan tujuan spesifik. Hal ini mendorong karyawan untuk melakukan yang terbaik bagi pencapain tujuan

Saran yang dikehendaki sehingga dapat berimplikasi pada peningkatan kinerja.

1. Memberikan tambahan informasi dan menimbulkan inisiatif untuk melakukan penelitian pada masa akan datang yang menjadi salah satu sumber dalam pengembangan Ilmu Akuntansi khususnya Akuntansi Sektor Publik

2. Difokuskan pada bidang anggaran, maka pada saat pengambilan data sebaiknya di saat pemerintah daerah sedang menyusun anggaran sehingga informan yang diperoleh bukan hanya pada aparat pemerintah daerah dan DPRD saja tetapi dapat diperoleh dari masyarakat

3. Bagi aparat pemerintah dalam penelitian ini sebaiknya lebih lagi mendalami menggunakan karakteristik tujuan anggaran agar menjadi pedoman, acuan atau tolok ukur dalam setiap penyusunan anggaran

\section{DAFTAR PUSTAKA}

Aimee, F dan Carol E, 2004. Aligning Priorities In Local Budgeting Processes. Journal of Public Budgeting, Accounting \& Financial Management. Boca Raton Summer 2004 Vol. 16, Iss. 2 ; page 210 .

Agus, A. Setiawan (2010) Pengaruh Umpan Balik Anggran dan Kejelasan Sasaran Anggran terhadap Kinerja Manejerial Kabupaten Sukoharjo. (tesis).

Bastian, Indra.2001. Akuntansi Sektor Publik di Indonesia, Edisi I, BPFE UGM, Yogyakarta

Bastian, Indra.2006. Sistem Akuntansi Sektor Publik, Salemba Empat Jakarta.

Frisilia, Hafiz (2007) Pengaruh Partisipasi Anggaran terhadap Kinerja Manajerial PT. Cakra Compact Industries Allmuniun. (tesis)

Gunawan. R Sudarmanto.2005. Analisis Regresi Linier Ganda dengan SPSS, Graha Ilmu, Yogyakarta.

Graffiratna Cristie (2009) Pengaruh Partisipasi Anggaran, Tingkat Kesulitan Anggaran dan Evaluasi Anggaran terhadap Kinerja Majerial pada PT. PLN (Persero) APJ Surabaya Selatan. (tesis)

Handoko, T. Hani, (2000)Manajemen, Edisi 2, BEFE, Yogyakarta.

Istiyani (2009) Pengaruh Karakteristik Tujuan Anggaran Terhadap Kinerja Aparat Pemerintah Daerah di Kabupaten Temanggung, (Tesis)

Irianto H. Agus, 2004. Statistik : Konsep Dasar dan Aplikasinya. Cetakan Kedua. Penerbit : PT. Prenada Media, Jakarta 
Joko Susilo. 2008. Regresi Linear Dengan Variabel Moderating, http://jonikriswanto.blogspot.com/2008/08/.html

Kim, Jay S., Effects of Behavior Plus Outcome Goal Setting and Feedback on Employee Satisfacation and Performance. The Academy of Management Journal (Maret 1984) Hal 139-149.

Kenis, I., Effects of Budgetary Goal Characteristics on Managerial Attitudes and Performance. The Accounting Review (Oktober 1979). Hal 707-721

Libby, T. (2000) The Influence of Voice and Explanation on Performance in a Participativ Budgeting Setting. Accounting, OrganizationsThe Accciety). Hal 125-137

Mardiasmo.2002. Akuntansi Sektor Publik. Andi Yogyakarta.

Maryanti, H., A., 2002. Pengaruh Karakteristik Tujuan Anggaran Terhadap Perilaku, Sikap dan Kinerja Pemerintah Daerah di Propinsi Nusa Tenggara Timur. (Tesis)

Mulyadi. 2001. Total Quality Management. Edisi II. Penerbit Aditya Media. Yogyakarta.

Munawar,2006. Pengaruh Karakteristik Tujuan Anggaran Terhadap Perilaku, Sikap dan Kinerja Aparat Pemerintah Daerah di Kabupaten Kupang. (Tesis).

Michael, W. S dan Troy A, 2000. Financial Performance Monitoring and Customer Oriented Government : A Case Study. Journal of Public Budgeting Accounting \& Financial Management. 12 (1), 87-105.

Nor, Wahyudin.2007. Desentralisasi dan Gaya Kepemimpina Sebagai Variabel Moderating dalam Hubungan antara Partisipasi Penyusunan Anggaran dan Kinerja Manajerial, Simposium Nasional Akuntansi X Unhas Makassar.

Republik Indonesia. 2003. Undang-Undang No. 17 Tahun 2003 tentang Keuangan Negara. Komite Penyempurnaan Manajemen Keuangan Jakarta.

Republik Indonesia. 2004. Undang-Undang No. 32 Tahun 2004 tentang Pemerintah Daerah, Jakarta.

Republik Indonesia. 2005. Undang-Undang No. 33 Tahun 2004 tentang Perimbangan Keuangan Pusat dan Daerah, Jakarta.

Sadjiarto Arja,2000. Akuntabilitas dan Pengukuran Kinerja Pemerintah, Jurnal Akuntansi \& Keuangan Vol 2,Nopember 2000: 138-150

Sarjito, Bambang. 2007. Pengaruh Partisipasi Penyusunan Anggaran Terhadap Kinerja Aparat Pemerintah Daerah : Budaya organisasi dan Komitmen Organisasi sebagai Variabel Moderating, Simposium Nasional Akuntansi X Unhas Makassar.

Sartje, Prang (2010) Pengaruh Karakteristik Tujuan Anggaran Terhadap Kinerja Aparat Pemerintah Propinsi Sulawesi Utara. (tesis)

Sekaran, Uma. 2006. Research Methods for Business : A Skill Building Approach. Four Edition. New York: John Willey \& Sons, Inc.

Sugiyano. (2007). Statistika untuk penelitian, CV Alvabeta, Jakarta

Suryaningsih, (2007) Partisipasi dalam penyusunan anggaran terhadap prestasi manajer pusat pertanggungjawaban. (tesis)

Supranto, J. 2000. Statistik Teori dan Aplikasi, Edisi Enam. Jakarta: Erlangga 